\title{
9 The potential and the challenges of evaluations to positively influence reforms
}

\author{
Working with producers in the \\ Benin agricultural sector
}

\author{
Bonaventure Kouakanou, Dossa Aguemon, \\ Marius S. Aina, Abdoulaye Gounou and \\ Emmanuel M. David-Gnahoui
}

\section{Summary}

In 2006, a new President of Benin was elected with a particular interest in good governance. He considered public policy evaluation as key to good governance and established an Office for Evaluation of Public Policies and a national evaluation system (NES). This chapter focuses on an evaluation of the agricultural sector development policy in Benin that was carried out in 2009 at an early stage of the NES, and how the evidence was used to inform later policies. The research for this case study used qualitative and participatory methods, including a document review, 20 interviews and three mini-workshops. The 2009 evaluation was not used instrumentally, but it made a significant conceptual contribution in terms of understanding the needs of the sector. In 2008 to 2009, the role of civil society and agricultural producer organisations in policy development was transformed, and they began to play a key role in management of the sector. This case illustrates the potential for evaluations to inform policy making and implementation in Benin, and the challenges of doing so. The role of producer organisations was key to the uptake of evidence into policy, based on a more inclusive and effective process of evidence generation and use.

\section{Background}

In 2006 a new President of Benin was elected. President Boni Yayi considered public policy evaluation as key to good governance and established an Office for Evaluation of Public Policies (Bureau d'Évaluation des Politiques Publiques (BEPP, later BEPPAAG)) and a national evaluation system (NES). Benin is now one of three African countries with a formal national system for the evaluation of public policies and programmes, along with Uganda and South Africa.

This chapter focuses on an evaluation of the agricultural sector development policy which was carried out in 2009. The research for the chapter involved qualitative and participatory methods that included document review, 20 interviews and three mini-workshops. Participants in the workshops and 
interviews included the minister, senior officials and monitoring and evaluation $(\mathrm{M} \& \mathrm{E})$ managers of the Ministry of Agriculture and other ministries, development partners (DPs), representatives of civil society organisations (CSOs) and members of producer unions and agricultural professional organisations. The co-authors include the deputy minister and senior officials from the ministry.

\section{The use of evidence in agricultural policy in Benin}

\section{Background to the case}

The main stakeholders in the agricultural sector include the presidency, the Ministry of Agriculture, Livestock, and Fisheries (MAEP) and ministries involved in related activities (finance, development, environment, decentralisation, water and sanitation, health, education, etc.). Decentralisation to communes (local governments) means local governments have a role in projects in their area (MDGLAAT, 2010, p. 25).

In terms of non-government actors, the Platform of Civil Society Organisations in Benin (PASCiB) is a national organisation which is influential in decision making in the agricultural sector. The National Platform of Agricultural Farmer and Producer Organisations (PNOPPA) also plays a strong role. Producer unions are federated to PNOPPA, which organises services to members such as procurement, market research, marketing support and facilitation of access to finance.

DPs have been catalysts and facilitators in the development and even implementation of agricultural policies in Benin. DPs support evaluations and research and most evaluations are funded by DPs. In several cases DPs have supported professional or civil society organisations, which has strengthened their influence in decision making. At present DPs are very influential in shaping public-sector policy.

\section{The journey of the agricultural sector development policy}

From 1990 to 2019 Benin's agricultural sector underwent various policy changes. In this section we follow this evolution and highlight the mechanisms that influenced their development. ${ }^{1}$ Figure 9.1 provides an overview.

In July 1990 the Marxist military government was replaced by a democratically elected government. The Letter of Declaration of Rural Development Policy (LDPDR) of May 1991 was the first policy document of the so-called democratic renewal era in Benin and it initiated the state's withdrawal from the activities of production, marketing and processing, and the transfer of those roles to other stakeholders including producer organisations and the private sector (MDR, 2000, p. 4).

The second policy document, the Declaration of Rural Development Policy (DPDR), came into force in July 2000.

In March 2006, a new government was elected under President Boni Yayi, who expressed concern about the lack of capacity in the agricultural sector and the desire to rapidly strengthen the sector. The Ministry of Agriculture developed a strategic plan for the revival of the agricultural sector, the Plan Stratégique 


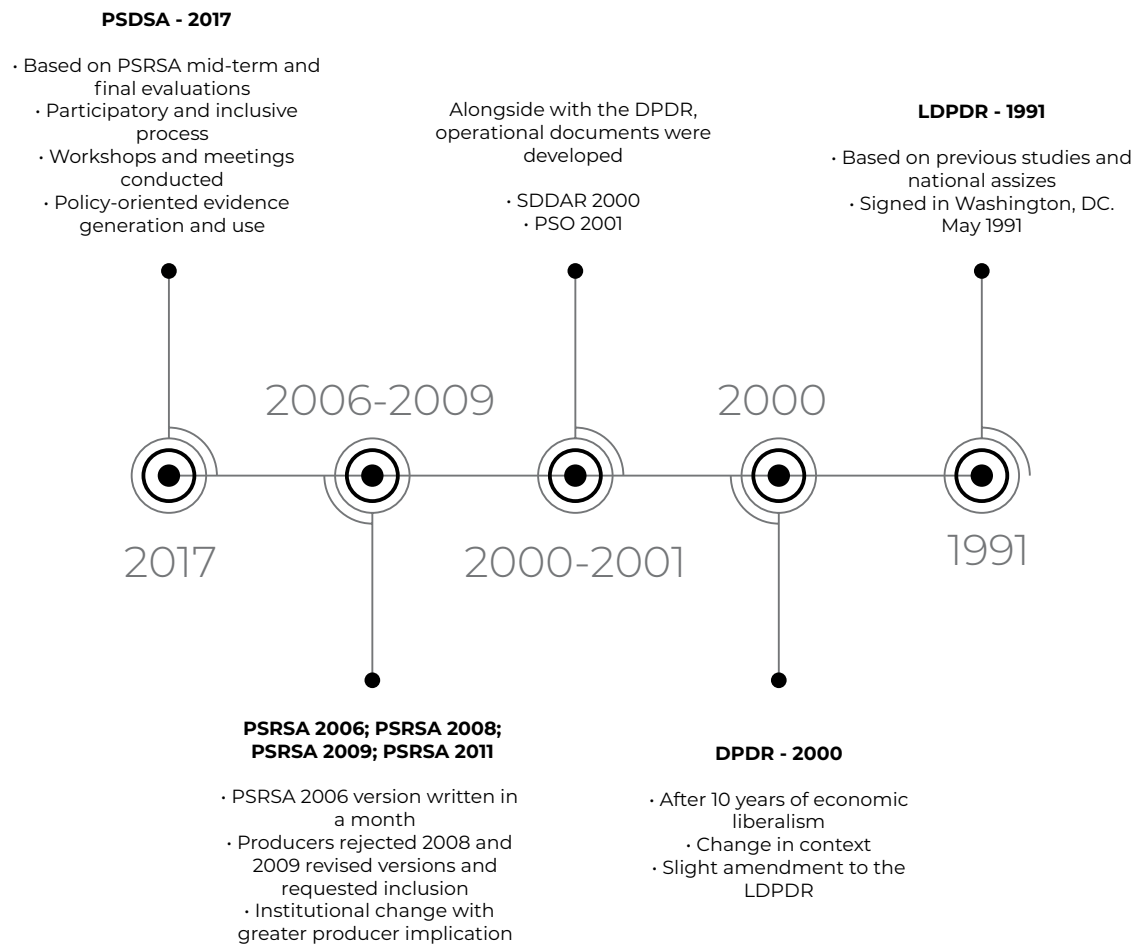

LDPDR: Letter of Declaration of Rural Development Policy; DPDR: Rural Development Policy Declaration; SDDAR: Master Plan of the Agricultural and Rural Development Sector; PSO: Strategic Operational Plan; PSRSA: Strategic Plan for the Revival of the Agricultural Sector; PSDSA: Strategic Plan for the Development of the Agricultural Sector

Figure 9.1 The journey of the agricultural sector policy

Source: Author generated.

pour la Relance du Secteur Agricole (PSRSA) 2006-2015. The ministry developed the plan internally and in only one month.

The PSRSA was a great improvement compared to former policy documents. However, it was rejected by producer unions and DPs, because of their exclusion from its formulation. After intense and lengthy discussions, a more inclusive revision process was initiated. The second version of the PSRSA was the subject of a government seminar on 12 June 2008. The recommendations of this seminar were followed up by a group of technical staff from the Ministry of Planning and from the Ministry of Agriculture. The validation of the 'new' PSRSA took place on 30 July 2008 after a stakeholder validation workshop. DPs expressed reservations about the content (Mongbo and Aguemon, 2015, p. 8), which were endorsed by PNOPPA, which criticised the ministry staff for 'treating other actors in the agricultural sector as their subjects' (Ibid., p. 8). 
For some public servants, revising the PSRSA questioned the skills of the technical group that drafted it. However, the dependence of the agricultural sector on DPs for funding and the DPs' financial support to the revision process (Ibid.) led to the relaunch of the PSRSA review process in April 2009. Several workshops were held which were inclusive and participatory and led to a critical reduction of the influence of the ministry. PNOPPA's role in the workshops was significant, through the quality of its proposals and the contribution of its representatives within the extended workgroup and the technical subcommittees (Ibid., p. 13).

Despite this move to wider inclusion, a ministerial decree in February 2010 established a steering committee to work on the finalisation of the policy without any prior consultation and with only a single representative of nonstate actors on one subcommittee (Mongbo and Aguemon, 2015, p. 10). After consulting with representatives of civil society, PNOPPA made a counterproposal recognising the increasing importance given to producer organisations in the agricultural policy of ECOWAS. As a result, non-government players took on more prominent roles and the technical subcommittee was chaired by a senior technical official from the Ministry of Agriculture rather than a politician (Mongbo and Aguemon, 2015)

\section{The 2009 evaluation happens in parallel}

Meanwhile, BEPP was starting the new evaluation system and an evaluation of policies in the agricultural sector was scheduled for 2008 as one of the first evaluations of the new system. The aim of the evaluation was to carry out a diagnosis and propose approaches for the revival of the sector. The evaluation was managed by a steering committee which validated the methodological framework and ensured that the assessment was conducted independently. Members of the steering committee were drawn from the President's Office and from the ministries of planning, finance and agriculture, and included professionals from the Benin M\&E Association.

The evaluation was conducted by an independent service provider and was of good quality. Evaluation professionals, other ministry agents, the President's Office and DPs contributed extensively to discussions based on the solid evidence provided by the evaluators. This brought a range of stakeholders into the learning from the evaluation. A three-day stakeholder validation workshop involving a wide range of stakeholders was held in December 2009, during which the final evaluation report was endorsed.

Meanwhile, over 2008-2009, institutional reshuffling was taking place within the agricultural sector. The evaluation report came out in December 2009, at a time when changes in the institutional framework made it easier for producers to be involved in policy-making processes and utilisation of evaluation results.

The results and recommendations of the evaluation (Table 9.1), many of which were focused on the PSRSA, brought forward evidence needed the right moment, and the recommendations helped design effective policies for the sector that are still in force to date. 
Thus, after the 2009 evaluation and as part of the revision of the PSRSA, the institutional framework for policy orientation and monitoring included the following guiding principles for governing the agriculture sector:

- Participation of all actors;

- Clear division of roles and responsibilities among key stakeholders;

- Public-private partnerships for agricultural development;

- Refocusing and strengthening of the state in its regulatory functions;

- Empowerment of all actors according to their mandates;

- Accountability

(MAEP, 2017a, p. 3).

The adoption of these principles strengthened stakeholder participation in agricultural policy development, making broad ownership and implementation more likely.

\section{The revisions to the PSRSA}

The revision of the PSRSA not only introduced non-government actors into policy making for the first time, but also initiated a process of improving data production and use. Evidence that came out of the 2009 evaluation became a significant input in developing subsequent sector policies (MPD, 2016, p. 6). This raised the profile of evaluation as a method for evidence generation and stimulated the demand for evidence. Thus, with the PSRSA, the demand for evidence became less for compliance, at the request of DPs or the ministry, and more use-oriented based on the actual needs of producers in the field.

The final version of the PSRSA (2011-2016) was adopted in September 2011 (MAEP, 2011). Mid-term and final evaluations of the PSRSA were carried out internally by MAEP in 2014 and 2016, reflecting that the ministry was committed to the process (MAEP, 2016). The evaluations were strongly supported by DPs, served as a baseline for the development of the PSDSA (Strategic Plan for the Development of the Agriculture Sector) and a solid foundation for writing the current PSDSA 2017-2025 and the PNIASAN, the National Plan for Agricultural Investment, Food Security and Nutrition, for 2017-2021.

\section{The strategic plan for the development of the agricultural sector-PSDSA $2017^{2}$}

In 2016 a new head of state was elected. Given that the head of state wanted to stamp his vision on the sector, the agricultural sector was asked to develop a new strategic plan for the development of the agricultural sector (PSDSA). The PNOPPA chairman noted how the ministry officials had been influenced by the PSRSA: As soon as this new vision was announced, ministry officials would take a recycled version of the old documents out of their laboratories and put it into effect. It's no longer the case now'. The establishment of an inclusive institutional framework had created an environment where the development of public policy is no longer just the responsibility of the ministry. As noted by a respondent from Belgian Cooperation, 'the empowerment of producer organisations had a huge impact. Whether it is the National Chamber of Agriculture, 
PASCiB or PNOPPA, these organisations have become indispensable and even take the lead on several issues'.

The PSDSA 2017 had the advantage of being developed using evidence from the independent 2009 evaluation and internal 2014 and 2016 evaluations of the PSRSA by the ministry. According to the director of planning, the incorporation of evidence into PSDSA development has systematised the approach and strengthened relevance and stakeholder ownership. The first PSRSA of 2006 was produced in only one month. It took 18 months to finalise the PSDSA 2017 through a much more effective and inclusive process. However, the predominant role of non-state actors holds the potential for greater ownership and more effective implementation.

\section{Why evaluations were required and the role that evidence generation played}

\section{From evidence generation to utilisation}

The evaluation of the agricultural sector, which was completed in 2009, was good quality and very credible. At first MAEP staff rejected the evaluation results because of sensitivity that the evaluation was too critical.Then, the Ministry of Planning and Development took over the management of the evaluation and chairing of the steering committee. The final validation occurred after a laborious process. The report remains one of the best evaluations to date and has been referred to extensively.

Table 9.1 shows the recommendations of the evaluation report (2009), and the degree to which the recommendations have been implemented.

The results of the 2009 evaluation were shared at a three-day stakeholder validation workshop, which enabled stakeholders to engage with the findings. Benin's NES did not specify a formal process to take forward the recommendations, such as an improvement plan. However, because stakeholders had participated in the validation workshop they internalised the findings and were able to use these when the opportunity emerged. Note that there is now a follow-up mechanism to see where recommendations have been implemented and by whom.

Towards mid-2010, agricultural sector stakeholders had the urgent task to complete the revision of the PSRSA. The most available and reliable evidence at that moment was the freshly validated results of the 2009 sector evaluation. Meetings were held where the methodology for development of the PSRSA was reviewed in light of the evaluation results and recommendations. These meetings included formal meetings, workshops and thematic group work, lobbying, and advocacy by different categories of actors involved in the agricultural sector. A roadmap was defined and agreed, and a list of themes on which different groups should work. Leaders were designated for each theme on the basis of their skills rather than their position in the public administration (Mongbo and Aguemon, 2015, p. 10). Thus, non-state actors including producer unions, CSOs and chambers of commerce fully entered public policy-making processes in the agricultural sector, with the support of DPs. 
Table 9.1 Recommendations from the 2009 evaluation and what has been implemented

\begin{tabular}{|c|c|c|}
\hline & Recommendations & Subsequent policies and implementation \\
\hline \multirow{2}{*}{ 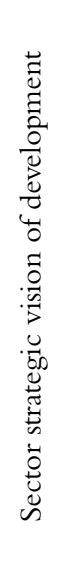 } & $\begin{array}{l}\text { 1. MAEP develops a new } \\
\text { agriculture sector policy } \\
\text { in line with Benin's new } \\
\text { development orientation }\end{array}$ & $\begin{array}{l}\text { The existing PSRSA policy was revised and } \\
\text { adopted by government in October 2011. At } \\
\text { the end of the 2011-15 PSRSA, the mid-term } \\
\text { and final evaluations were used for drafting the } \\
\text { PSDSA 2017-2025 and its operational plan. } \\
\text { They were both adopted by the government in } \\
\text { November 2017. }\end{array}$ \\
\hline & $\begin{array}{l}\text { 2. Government prepares and } \\
\text { Parliament adopts a law } \\
\text { on agriculture adapted to } \\
\text { the vision of the emerging } \\
\text { economy and Benin's } \\
\text { strategic development } \\
\text { approach }\end{array}$ & $\begin{array}{l}\text { The draft law is being finalised, pushed by } \\
\text { producer unions and civil society actors and } \\
\text { supported by DPs. } \\
\text { - Parliament required an ex-ante evaluation prior } \\
\text { to the introduction of the law. } \\
\text { - Approval of the law is a conditionality for } \\
\text { key EU funding. The adoption of the law is } \\
\text { expected to be completed by September } 2019 \text {. } \\
\text { The EU will monitor progress. }\end{array}$ \\
\hline 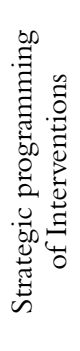 & $\begin{array}{l}\text { 3. Government considers } \\
\text { the } 2006 \text { version of the } \\
\text { PSRSA as an interim } \\
\text { strategic plan pending } \\
\text { drafting of a new } \\
\text { agricultural sector policy } \\
\text { and adoption of a law on } \\
\text { agriculture }\end{array}$ & $\begin{array}{l}\text { See recommendation } 2 . \\
\text { In addition to the drafting of the new agricultural } \\
\text { sector policy, other documents were produced, } \\
\text { including: the promotion of } 13 \text { agricultural } \\
\text { sectors; the establishment of an efficient financing } \\
\text { system for the agricultural sector; implementation } \\
\text { of the institutional and organisational reform } \\
\text { of the ministry; the establishment of the Benin } \\
\text { Agency for the Promotion of AgriculturalValue } \\
\text { Chains (ABePROFA). }\end{array}$ \\
\hline \multirow{4}{*}{ 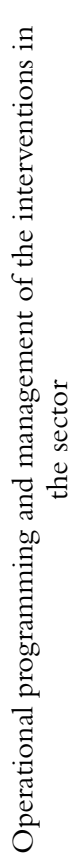 } & $\begin{array}{l}\text { 4. Government provides } \\
\text { sufficient funding for the } \\
\text { agricultural sector (as } \\
\text { per Maputo and Malabo } \\
\text { commitments) }\end{array}$ & $\begin{array}{l}\text { Not implemented. On average, over the } 2011- \\
2017 \text { period, } 7 \% \text { of total state expenditure } \\
\text { was invested in the agriculture sector, without } \\
\text { reaching the } 10 \% \text { recommended (MAEP, } \\
2017 \text { e). }\end{array}$ \\
\hline & $\begin{array}{l}\text { 5. MAEP develops synergy } \\
\text { between educational and } \\
\text { agricultural policy reforms }\end{array}$ & $\begin{array}{l}\text { This did not happen. There is still institutional } \\
\text { fragmentation. (DPP MAEP, 2015). }\end{array}$ \\
\hline & $\begin{array}{l}\text { 6. The ministry implements } \\
\text { strategies to facilitate } \\
\text { access to inputs specific to } \\
\text { agriculture sectors other } \\
\text { than cotton }\end{array}$ & $\begin{array}{l}\text { Several initiatives on the implementation of } \\
\text { specific inputs have been carried out without } \\
\text { leading to an appropriate mechanism for } \\
\text { distribution of specific inputs. }\end{array}$ \\
\hline & $\begin{array}{l}\text { 7. The ministry sets up a } \\
\text { consultation framework for } \\
\text { synergistic implementation } \\
\text { of projects and } \\
\text { programmes }\end{array}$ & $\begin{array}{l}\text { In } 2013 \text { the National Guidance and } \\
\text { Monitoring Council (CNOS) was created } \\
\text { for implementation of the PSRSA, but } \\
\text { only established in December 2015, one } \\
\text { month prior to the end of the PSRSA. Thus, } \\
\text { coordination and monitoring of the PSRSA at } \\
\text { the strategic level was not effective during this } \\
\text { period. However, the CNOS reform has been } \\
\text { well implemented and today it has } 12 \text { regional } \\
\text { and } 77 \text { local branches, one for each region and } \\
\text { local government (commune). }\end{array}$ \\
\hline
\end{tabular}




\begin{tabular}{|c|c|}
\hline Recommendations & Subsequent policies and implementation \\
\hline $\begin{array}{l}\text { 8. The ministry adopts } \\
\text { results-based management } \\
\text { tools with a well- } \\
\text { functioning M\&E system } \\
\text { with performance and } \\
\text { impact indicators for each } \\
\text { program and project }\end{array}$ & $\begin{array}{l}\text { A number of executives have been trained but } \\
\text { most have retired. The capacity-building } \\
\text { process for new managers at both central and } \\
\text { decentralised levels was continued with donor } \\
\text { support. } \\
\text { Currently EU funding and capacity building are } \\
\text { being used on the Programming, Planning, } \\
\text { Budgeting and Monitoring chain for different } \\
\text { stakeholders in the agriculture sector including } \\
\text { non-government actors. This will assist with } \\
\text { real-time production of implementation data of } \\
\text { flagship projects. }\end{array}$ \\
\hline
\end{tabular}

Source: The recommendations are taken from the report on the evaluation of agricultural sector development policy (December 2009) and the subsequent policies are drawn from key-informant interviews.

Since 2011, PNOPPA has initiated a significant number of studies, the most important being the ones that generated the Farmer Memorandum, a consensus document produced after more than 40 meetings at local, regional and national levels that summarised the expectations of stakeholders on the content and orientation of the law on the agricultural sector (PNOPPA, 2016, p. 4). According to the former president of the platform, 'transparency and evidence use have become systematic in their operating mode; for their own reputation, every decision has to be evidence-based'.

A Conseil National d'Orientation et de Suivi (CNOS) - National Guidance and Monitoring Council - was established in February 2013 to guide and regulate the national agricultural sector development policy. It is a publicprivate partnership formalised through a framework agreement, specially established to encourage the private sector to invest in the agricultural sector. It is chaired by the president and has 25 members, including ten ministries, the Benin Chamber of Agriculture, the Benin Chamber of Commerce and Industry, PNOPPA, PAS$\mathrm{CiB}$, and the National Association of Local Governments of Benin (ANCB). It has structures at regional and commune level with decision-making autonomy and they provide reasoned opinions on all issues related to agricultural sector policies and strategies (Government of Benin, 2013). CNOS has been critical in developing and maintaining a culture of planning, monitoring and evaluation in the whole agricultural sector. Its local branches involve grassroots actors in monitoring agricultural information. They produce data on areas to be planted, input requirements and yield per hectare, and propose corrective measures to improve production. In doing so, the CNOS, especially at the local level, has increased producers' capacity, and their participation in the collection of basic data for evidence generation. Such information is the centrepiece of the collection of statistics that is treated and consolidated at the level of the Directorate of Agricultural Statistics.

The quality of evidence from the 2009 evaluation helped stimulate demand for further studies. Since 2011, PNOPPA has initiated a significant number of studies, ranging from A Document Review on the Maize Sector and Its Added 
Value Chains in Benin (June 2011) to A Study on the Cash Purchase of Fertiliser by Producers in Benin (October 2011). Those studies responded to the needs in the field and led to development of a policy for the maize sector, as well as for sectors such as cassava, rice, cashew, pineapple, aquaculture, milk, table eggs, meat and market gardening, and so policy making has become more evidence-based.

\section{Unintended consequences}

The 2009 evaluation was carried out at the same time as a major transformation of the institutional framework, with the strengthened role of PNOPPA. With this strengthened collaboration among stakeholders, the evidence produced by the 2009 evaluation was used as the basis of new policies including the introduction of sector legislation and the inclusive and evidence-based development of the PSDSA. Moreover, from there on, evidence was used more extensively in decision making. Table 9.1, summarises how far the evaluation recommendations have been acted on. As can be seen, the evidence informed several noteworthy changes including changes to the law, development of subsequent studies such as on maize (which resulted in a new maize policy), establishment of CNOS, capacity development programmes and so forth. Thus the 2009 evaluation has had a significant influence on the progress of the agricultural sector.

The PSRSA review was a historic trigger that profoundly changed the status quo in the agricultural sector. The institutional framework in force today is based on a proposal by the PNOPPA which, until 2008, had never played a significant role in informing policy but is today leading in introducing legislation for the agricultural sector.This change is the most important unintended consequence arising from the implementation of the agricultural sector policy and related processes.

\section{What promoted or inhibited use of the evaluation?}

This section explores the way use of the evaluation results and other evidence was promoted, using the analytical framework from Chapter 2. We analyse the type of use that happened, what interventions promoted use, and the factors that helped or hindered use.

\section{How do we understand the use that happened?}

In the analytical framework we refer to instrumental, conceptual, process and symbolic use. In terms of instrumental use, recommendations 1 and 2 from the 2009 evaluation (see Table 9.1) were directly implemented and the revision of the PSRSA was completed as advised in 2011. The process leading to the adoption of the agriculture sector orientation law is underway. Recommendations to become inclusive of producers were taken on board.

However, the biggest impact has been conceptual use. The evaluation report stands as a major landmark for the quality and quantity of the information it brought which helped to bring clarity to the sector. It informed subsequent discussions developing the PSRSA. In the introduction of the Farmer Memorandum, 
almost all the background information utilised came from the evaluation report. The cross analysis of previous policy documents showed their limitations and facilitated the use of the evaluation to inform the revision of the PSRSA.

In terms of negative symbolic use, the previous history was of public policies in the agriculture sector in Benin being developed by the ministry for compliance purposes, without involving stakeholders. In terms of positive symbolic use, as one of the first evaluations commissioned by the BEPP, the 2009 agricultural sector evaluation enhanced the importance of evaluations in providing evidence for policy making and implementation.

Process use can also be seen, that is use not from the findings but from the learning process which the evaluation supported, and the ownership assumed by producers in policy design processes. The experience of the revision of the PSRSA created awareness of the importance of a more inclusive and collaborative platform of stakeholders. That context fostered the use of evidence and therefore more demand for generation of user-oriented evidence. Many studies, especially the ones on the 13 targeted agricultural sectors, were commissioned by producer associations for their own use, based on the evaluation recommendations.

\section{What interventions promoted use?}

Table 9.2 summarises some of the interventions which we see operating in this case.

A key factor in the use of the evaluation was the quality and impartiality of the evidence from the 2009 evaluation that showed the value of sound evaluations as promoted by the NES. ${ }^{3}$ When the urgent task came to complete the revision of the PSRSA, the most readily available credible evidence at that moment was the freshly validated results of the 2009 evaluation, and the same stakeholders who had validated the results of the 2009 evaluation were able to use that understanding to inform the development of the subsequent policy.

\section{What enabled and what hindered the use of evidence?}

\section{Factors enabling use}

The establishment of a national evaluation system: The presence of BEPP (Bureau for Evaluation of Public Policies) resulted in an evaluation being conducted that might otherwise not have happened, and ensured its quality and independence. The NES has progressively become established and a theory of change is now a mandatory criterion for the eligibility of projects or programmes for the Public Investment Programme (BEPPAAG, 2017).

The commitment of non-state actors and their pressure on government: The opening of the policy space to include non-state actors like PNOPPA, PASCiB and chambers of agriculture and commerce created a revolution in policy making in agriculture in Benin. 
Table 9.2 Interventions that influenced use

\begin{tabular}{|c|c|}
\hline Intervention & Effect \\
\hline \multicolumn{2}{|c|}{ Elements of the emerging NES } \\
\hline $\begin{array}{l}\text { Focus on making the } \\
\text { evaluation credible }\end{array}$ & $\begin{array}{l}\text { The approach in the NES was to outsource evaluations } \\
\text { and commission a consultant using an external } \\
\text { recruitment process. This resulted in a good quality, } \\
\text { impartial evaluation. }\end{array}$ \\
\hline $\begin{array}{l}\text { Evaluation Steering } \\
\text { Committee comprising } \\
\text { key stakeholders }\end{array}$ & $\begin{array}{l}\text { The fact that the steering committee brought together key } \\
\text { stakeholders facilitated the subsequent ownership of the } \\
\text { results of the evaluation. The recommendations of the } \\
\text { evaluation were then used as the basic material for the } \\
\text { revision of the PSRSA. }\end{array}$ \\
\hline $\begin{array}{l}\text { Stakeholder validation } \\
\text { workshop }\end{array}$ & $\begin{array}{l}\text { A three-day workshop was held in December } 2009 \\
\text { during which the final evaluation report was approved. } \\
\text { This helped to build awareness of the importance of } \\
\text { good evidence, promoted interaction and involvement of } \\
\text { stakeholders and agreement on the emerging findings. }\end{array}$ \\
\hline Role of MAEP M\&E unit & $\begin{array}{l}\text { The MAEP M\&E unit organised the validation workshop } \\
\text { which played a key role in building interaction, awareness } \\
\text { and agreement amongst stakeholders. }\end{array}$ \\
\hline $\begin{array}{l}\text { The report was made } \\
\text { public }\end{array}$ & $\begin{array}{l}\text { The report is available and accessible online. As one of the } \\
\text { first evaluation reports of the newly established NES, it } \\
\text { served as a reference for users. }\end{array}$ \\
\hline \multicolumn{2}{|c|}{ Other elements contributing to use } \\
\hline Communication of results & $\begin{array}{l}\text { After the stakeholder workshop, there was an immediate } \\
\text { opportunity for use in the revision of the PSRSA. The } \\
\text { same stakeholders were also the ones working on the } \\
\text { PSRSA revision. This helped a lot in the ownership of the } \\
\text { results and their consequent use. }\end{array}$ \\
\hline $\begin{array}{l}\text { Steering committees for } \\
\text { policy development }\end{array}$ & $\begin{array}{l}\text { After the contention on development of the PSRSA, non- } \\
\text { state actors played key roles in steering committees for } \\
\text { policy development, promoting ownership and motivation } \\
\text { from these actors to champion the new policies. }\end{array}$ \\
\hline Dialogue processes & $\begin{array}{l}\text { Different types of meetings were held with stakeholders in } \\
\text { the agricultural sector where the PSRSA development } \\
\text { methodology was reviewed in light of the evaluation } \\
\text { results and recommendations, a roadmap drawn up and } \\
\text { themes taken forward. }\end{array}$ \\
\hline Advocacy by DPs & $\begin{array}{l}\text { The unhappiness of DPs with the emerging content of } \\
\text { the early PSRSA led to other stakeholders having the } \\
\text { confidence to raise concerns, notably in relation to the } \\
\text { dominant role of MAEP. }\end{array}$ \\
\hline $\begin{array}{l}\text { Capacity building of } \\
\text { producers by DPs }\end{array}$ & $\begin{array}{l}\text { Strengthening of PNOPPA, in particular, gave producers } \\
\text { the ability to play a strong role in the policy process. }\end{array}$ \\
\hline Study tour to Mali & $\begin{array}{l}\text { A study tour to Mali generated awareness and commitment } \\
\text { amongst stakeholders. }\end{array}$ \\
\hline
\end{tabular}


Active role played by DPs: The involvement of non-state actors was sustained by DPs. DPs provided financial and technical assistance and capacity-building to ministries, civil society, producers' unions, chambers of agriculture, NGOs and so forth.

Donor conditionalities:The World Bank and the EU's conditionalities in budget support mean that the realisation of certain indicators triggers financial bonuses. In 2017, an allocation of EUR 11 million from the EU was dependent on achieving the indicator: 'The Government has adopted the sector policy documents over the period 2017-2021 (PSDSA/PNIASAN)'.

The need for more relevant evidence: Many interview respondents highlighted the need for evidence to be relevant. The production of evidence is not a weak link in policy development in Benin; it is rather the relevance of the evidence. In this case, evidence generation has gained impetus because (1) demand for evidence has increased and (2) since the policies are more relevant, they need a more diversified base of more reliable evidence.

Establishing rules in favour of evidence generation and evaluation: It has become mandatory to use reliable data to inform policies and programmes. From the 2014 fiscal year parliamentary budget discussions, the Parliament of Benin made it obligatory for the government to conduct ex-ante evaluations prior to the submission of any project or programme for which ratification is required. ${ }^{4}$ This provision promotes the production of evidence and will boost future demand.

\section{Factors inhibiting evidence use}

Repeated structural reforms on paper without time to implement and learn: After every election, governments change and so policies change. In agriculture there have been ten ministers in ten years, seriously undermining institution building. Many ministers reinvent programmes and policies and ignore well-founded public policies initiated by a predecessor. Frequent reforms mean that emergent programmes do not have time to bear fruit. These then restart from zero. ${ }^{5}$

Fear of the unknown and reluctance to abandon routine practices: 'That is the way we do things' expresses experience and know-how but it can also hinder adjustment to the current situation. The fear of losing power and control over interventions in the sector explains how a PSRSA steering committee was appointed made up almost exclusively of civil servants, despite a prior decision to involve producers.

Lack of communication among stakeholders: The ability to work together to drive a policy process assumes skills in collaboration that the sometimes-opposing positions of the actors do not always allow. Government actors have a tendency to claim official legitimacy and consider themselves superior to other actors.

Administrative red tape: Public administration at all levels is ponderous and slow-moving. A promising study may be abandoned because no one has championed it. After the 2009 evaluation, there were multiple unproductive meetings of high-level officials which did not result in action. 
Inadequate resources: The PSRSA needed to be revised in 2009, but it could not be done as there was no budget. Inadequate resources affect the ability of actors to plan or to set up reliable $M \& E$ mechanisms. The reverse also happens, that is planning is not realistic for the resources likely to be available.

\section{Conclusions and emerging lessons}

\section{From ticking the box to actual evidence-based policy and practice}

In the past, although the process of revising agricultural policies did include stakeholder consultations, the policy documents were written by departmental staff. The actual clients were not able to contribute their lived experience. Historically, the writing of policies was more concerned with fulfilling the requirement of producing a document than developing a well-thought-out and implementable policy to be taken forward systematically. Few actors, including ministry officials, actually read the policy documents. None of these documents succeeded in transforming the sector until the involvement of producers, CSOs and chambers of agriculture in sector decision making. Stakeholders claimed their right to participate. 'It is about us the producers; you do not do us a favour by involving us!' (President of PNOPPA, Feb 2019.).

\section{How did the context and intervention influence the use of evidence}

What can we learn about evidence use arising from the Benin case? In the context of the 2009 evaluation, the policy space was dominated by government, with policies being revised frequently on paper, without effective diagnoses, and without the opportunity to really implement them.

A credible evaluation was undertaken (evidence generation) with relevant findings and recommendations, and having a NES helped ensure evaluation quality (use intervention). Most of the stakeholders that validated the evaluation final report were then involved in the restructuring of the sector's institutional framework. They seized the opportunity of the available evidence to complete the revision of the PSRSA, and the PSRSA of 2011 bears a strong imprint from the 2009 evaluation.

The context changed after 2010 with the involvement of producers. The context was now much more integrated, with government working closely with non-state actors, and there was much more drive from the producers to ensure that policies were relevant, and that appropriate strategies were implemented. In this context we see more examples of evidence generation, for example studies for the development of 13 sector value chains. A wider range of use interventions was applied, including involvement of all stakeholders through a series of dialogues, study tours, systematisation of data collecting and use for cotton campaigns, value chain development to increase production of food crops, enhancement 
of evidence management through the establishment of a directorate for agricultural statistics and so forth. We see higher levels of capability and motivation at individual and organisational levels. In terms of outcomes we see the policies agreed with stakeholders, a law on the agriculture sector, the creation of the CNOS, capacity development programs for ministry staff and producers with agreement between stakeholders on ways forward, much wider awareness of the results of evidence generation, and ultimately use. As a result of implementing many of these recommendations, Benin is now the biggest producer of cotton in Africa.

\section{Emerging lessons}

The process of researching and writing this chapter has itself been a learning opportunity for the agricultural sector, both for the MAEP and other stakeholders, and for the NES. It shows:

- The importance of conducting high quality evaluations. The rigour and quality of the evidence generated by the 2009 evaluation motivated stakeholders to trigger structural change in the sector's institutional framework.

- The importance of timing. Having evidence available at a time of change motivates use. This points to the need to anticipate and develop an evidence base prior to when it is actually needed, so that policy and decisions can be undertaken relatively quickly.

- The importance of a national evaluation system to promote use. A NES can ensure the involvement of stakeholders, develop systems like improvement plans, promote effective dialogue in the sector, and ensure that there is a knowledge broker in the ministry and/or in BEPP who will make sure that the results get used.

- The importance of involvement and commitment from key stakeholders including the clients of the system, which can stimulate the effective use of evidence. This helps build the momentum for change.

- The importance of development partners. DPs provide critical support to stakeholders and in taking processes forward. The technical assistance and the financial resources for non-state actors are extremely important. There are limitations because of DPs' project orientation, as projects have a limited life, and overreliance on DPs can cause a sustainability challenge. Also DPs have their own agendas which have to be managed.

\section{Concluding remarks}

What answers will the coalition with producers bring to the sector's questions related to planning, $M \& E$, financing, human resources, access to quality inputs, 
standardisation, revitalisation of production, processing, marketing and so forth? The role of the MAEP has become more complex and it struggles with how best to operationalise the complementarity between central government and producers. Producer unions and CSOs are not yet sufficiently established to fulfil the roles potentially assigned to them.

The evaluation system in Benin is becoming more institutionalised, with the decision in 2019 to have an ex-ante evaluation prior to any projects, programmes or action plans being submitted for approval. ${ }^{6}$ The decision to have theories of change for new programmes and policies should help implementation planning and suggests a focus on programme implementation.

Ten years after the 2009 evaluation of the agricultural sector development policy, the sector bears the imprint of the changes that occurred. The evaluation recommendations are a landmark in evidence around the changes occurring in the sector. A noteworthy lesson is the necessity to provide an institutional framework which involves producers. Without this, evidence generation is unlikely to result in use.

Annex 9.1 Summary of the main landmarks in Benin's agriculture sector 1990-2009

\begin{tabular}{ll}
\hline Year & Main landmark \\
\hline 1991 & The Letter of Declaration of Rural Development Policy (LDPDR) \\
1993 & Development of the National System of Agricultural Extension \\
1994 & Strategy Document and Action Plans for the Livestock Sub-sector \\
1995 & Programme for the Restructuring of the Agriculture Sector \\
1995 & Round Table on the Rural Sector (September) \\
2000 & The Declaration of Rural Development Policy (DPDR) \\
2000 & The Master Plan for Agricultural and Rural Development \\
2001 & The Strategic Operational Plan \\
2001 & Sub-sectoral and Transversal Action Plans \\
2001 & Creation of the Network of Benin Chambers of Agriculture \\
2001 & National Strategy Document for the Cotton Sector \\
2001 & National Policy for the Promotion of Women in the Rural and Agricultural \\
& Sector \\
2001 & Adoption and Implementation of Programme - Budget Approach \\
2001 & Agricultural Millennium Development Goals \\
2004 & Reform of Local Centres for Agricultural Development \\
2006 & The Strategic Plan for the Revival of the Agricultural Sector (PSRSA) \\
2006 & Growth and Poverty Reduction Strategy Document \\
2007 & Recruitment of 2,000 trainers for Local Centres for Agricultural Development \\
2007 & Signature of Economic Partnership Agreements with the European Union \\
2007 & Advisory Policy for Family Farming \\
2007 & Implementation of the System of Representation of Agricultural Professional \\
& Associations
\end{tabular}

Source: MPDEPP-CAG. 2009, Benin Agriculture Sector Evaluation Report, p. 28. 


\section{Notes}

1 The 2009 evaluation report has a whole section devoted to the analysis of the different policies from a historical point of view (pp. 24-46). Much of the information presented in the journey of the policy comes from this report.

2 The Strategic Plan for the Development of the Agriculture Sector; in French, Plan Stratégique de Développement du Secteur Agriculture (PSDSA), was adopted by the government in November 2017.

3 Many other public policies have been evaluated since and are made available on the Presidency of the Republic site (www.presidence.bj/evaluation-politiques-publiques).

4 The decision was made after the minister in charge of the evaluation of public policies made his budget presentation highlighting the importance of evaluation.

5 A typical example of this is the reforms of regional centres responsible for agricultural promotion for which the research did not identify any studies or evidence that indicated their soundness.

6 This came after the Minister for Evaluation of Public Policies made a presentation to support his departmental budget in \{arliament.

\section{References}

BEPPAAG. 2017. Guide méthodologique national d'évaluation. UNICEF. 124 pages. Bureau d'Evaluation des Politiques Publiques et de l'Analyse de l'Action Gouvernementale, Bénin.

Government of Benin. 2013. Request from the Government of Benin for financing of the food production support project in Alibori, Borgou and Collines Departments (PAPVI-ABC). Retrieved 23 August 2019, from www.gafspfund.org/sites/default/files/inline-files/4.\%20Benin_ GAFSP\%20proposal\%20EN.pdf.

MAEP. 2011. Plan stratégique de relance du secteur agricole (PSRSA). 107 pages. Ministère de l'Agriculture, de l'Élevage et de la Pêche, Bénin.

MAEP. 2015. Document actualisé de politique nationale des semences végétales - Benin. 20 pages. Ministère de l'Agriculture, de l'Élevage et de la Pêche, Bénin.

MAEP. 2016. Rapport d'évaluation du plan stratégique de relance du secteur agricole 2011-2015. 88 pages. Ministère de l'Agriculture, de l'Élevage et de la Pêche, Bénin.

MAEP. 2017a. Cadre institutionnel d'orientation et de suivi du secteur agricole. 24 pages. Ministère de l'Agriculture, de l'Élevage et de la Pêche, Bénin.

MAEP. 2017b. Cadre programmatique du secteur agricole. 148 pages. Ministère de l'Agriculture, de l'Élevage et de la Pêche, Bénin.

MAEP. 2017c. Plan Stratégique de Développement du Secteur Agricole (PSDSA) 2025 et Plan National d'Investissements Agricoles et de Sécurité Alimentaire et Nutritionnelle PNIASAN 2017-2021. 131 pages. Ministère de l'Agriculture, de l'Élevage et de la Pêche, Bénin.

MAEP. 2017d. Stratégie nationale de promotion des filières agricoles intégrant l'outil clusters agricoles. UFAI. 73 pages. Ministère de l'Agriculture, de l'Élevage et de la Pêche, Bénin.

MAEP. 2017e. Rapport de performance du secteur agricole, Gestion 2016.54 pages. Ministère de l'Agriculture, de l'Élevage et de la Pêche, Bénin.

MDGLAAT. 2010. Recueil de lois sur la décentralisation. 107 pages. Ministère de la Décentralisation, de la Gouvernance Locale, de l'Administration et de l'Aménagement du Territoire, Bénin.

MDR. 2000. Déclaration de Politique de Développement Rural. 27 pages. Ministère du Développement Rural, Benin.

Mongbo, R. and Aguemon, D. 2015. Action publique, acteurs, ressources et pouvoir: cas de la relecture du Plan Stratégique de Relance du Secteur Agricole au Bénin. Communication au Colloque 2015 de l'APAD. 
168 Bonaventure Kouakanou et al.

MPD. 2016. Synthèse de l'étude sur l'utilisation des résultats des évaluations réalisées au cours de la période 2010-2013. Direction Générale de l'Évaluation. 8 pages. Ministère du Plan et du Développement, Bénin.

MPDEPP-CAG. 2009. Évaluation de la Politique de Développement du Secteur Agricole au Bénin. Rapport Final. 137 pages. Ministère du Plan, du Développement, de l'Évaluation des Politiques Publiques et du Contrôle de l'Action Gouvernementale, Bénin.

PNOPPA. 2016. Imaginons et construisons ensemble le devenir de notre agriculture: Plaquette de mobilisation pour la collecte de fonds pour la réalisation du Mémorandum Paysan. 6 pages. Plateforme Nationale des Organisations de Paysans et de Producteurs Agricoles, Bénin. 